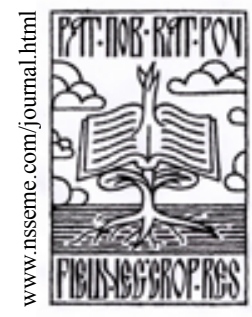

\title{
Interdependence between the Harvested Areas and Purchase Prices of Soybean
}

\author{
Danica Bošnjak • Emilija Nikolić Đorić • Vesna Rodić
}

\author{
received: 6 November 2013, accepted: 12 December 2013 \\ published online: 22 January 2014 \\ (C) 2013 IFVC \\ doi: $10.5937 /$ ratpov50-4827
}

\begin{abstract}
Summary: One of the most difficult issues of farm management is giving the answer to the question what to produce, i.e. making a decision about the sowing structure. Economic factors and principles play an important role in farmers' decisions about what to grow and on which areas. The purchase price of each crop, including soybeans, is an important but not the only factor of competitiveness. The authors of this paper started from the assumption that the level and trend of soybean purchase prices, among others, affect producers' decision on the growing area for this crop. Therefore, in order to scientifically confirm the initial assumption, an attempt has been made to examine (using appropriate statistical methods) the effect of average soybean purchase prices on the spread of this crop in Serbia.

Key words: average purchase prices, cross-correlation function, harvested areas, lagged correlation, power regression model, soybeans
\end{abstract}

\section{Introduction}

Organization of agricultural production, especially crop production is always associated with uncertainty and risks. This uncertainty and the necessity of accepting a certain level of risk require a specific approach to farm management, i.e. decision-making (Muller \& Abisija 2001, Birovljev \& Tomić 2009). Striving to achieve a more efficient use of available resources, especially land, decision-makers constantly face a number of questions and dilemmas. One of the most difficult issues of farm management is giving the answer to the question what to produce, i.e. making a decision about the sowing structure.

If the business decision process is based on economic objectives, which is most often the case, many authors (Reljin et al. 1996, Bošnjak \& Rodić 1999, 2006, 2010, Brodet et al. 2006), emphasize the role of economic factors and principles in farmers' decisions about what to grow and on which areas. Among other numerous economic

D. Bošnjak* • E. Nikolić Đorić • V. Rodić

University of Novi Sad, Faculty of Agriculture, Trg Dositeja Obradovića 8, 21000 Novi Sad, Serbia

e-mail:danicab@polj.uns.ac.rs factors, prices and their ratios are of particular importance (Birovljev 2001, Vlahović 2003, Milanović 1996, 2011, Milanović \& Stevanović 2012).

There are different price ratios in agriculture, while those that affect the sowing (production) structure, the level of intensity, as well as the degree of finalization of agricultural products are of particular importance. Price-parities among different crops and their changes influence the sowing structure, being one of the main factors which affect producers' decision about growing a certain crop and governing its distribution in a certain area. In this regard, in recent years soybean has become an increasingly competitive crop both globally (Burton \& Miranda 2013) and in our country, primarily in Vojvodina (Bošnjak \& Rodić 2010), employing significant capacities of arable land (Bošnjak \& Rodić 2011, Bošnjak 2012).

The purchase prices of each crop, including soybean, is an important but not the only factor

\footnotetext{
Acknowledgements:

This research is part of the projects No TR 31022 and TR 43007, financed by Serbian Ministry of Education, Science and Technological Development.
} 
of competitiveness. The purchase prices are always under the influence of the quantities produced (supply), demand, regional and world market prices. As such, it has a significant impact on the economic effects of each crop (Milanović 2011). Taking into account the above facts, the authors of this paper start from the assumption that the level and trend of changes of purchase prices of soybean significantly affect producers' decision about the growing area of this crop. Therefore, in order to scientifically confirm the initial assumption, an attempt has been made to examine (using appropriate statistical methods) the impact of average purchase prices of soybean on the spread of this crop in Serbia.

\section{Research Method and Data Sources}

In order to evaluate the characteristics of both the purchase prices and the most important characteristics of soybean production (harvested area, total production and yield per unit area) the main descriptive statistics indicators were used. Average annual growth rate of the observed soybean characteristics was determined using the model of exponential trend.

Regression model was applied to examine the interdependence of harvested area and average annual purchase price of soybeans. In order to perceive the lag effects of average annual purchase prices on the harvested areas of soybean in Serbia cross-correlation function was applied. The determined cross-correlation coefficients were estimated by the model given by Box, Jenkins and Reinsel (2008).

The main sources of data were obtained from the published reports of the National Bureau of
Statistics (www.stat.gov.rs). Time series analysis of the observed characteristics of soybean covers the period 1997-2011, while the spatial analysis covers the region of the Republic of Serbia. The obtained research results are presented in tables and figures.

\section{Results and Discussion}

\section{The Main Characteristics of Soybean Production}

During the observed period (1997-2011) soybean was grown in Serbia on the average area of 126,000 hectares. It occupied somewhat less than $4 \%$ of the total capacity of arable land in the country. Soybean production is mainly concentrated in Vojvodina province; about $93 \%$ of the total soybean area is in this region. Soybean takes up about $8 \%$ of the province total arable land.

Area under soybean demonstrates a permanent growth tendency, both in Serbia (the growth rate $5.61 \%$ ) and in Vojvodina (the growth rate 5.63\%). The analysis of shorter periods shows that the harvested areas of soybean increased by about 30 percentage points every five years (Table 1).

Determined coefficients of variation $(25.58 \%$ for Serbia and $25.8 \%$ for Vojvodina) indicate significant variability of the harvested area of soybean. However, this variability is lower than before, since Starčević et al. (2003), Bošnjak \& Rodić (2011) and Bošnjak (2012) pointed to even larger fluctuations in the harvested area in the past.

The increase in soybean area has been followed by a positive trend in the average yields (the growth rate $2.19 \%$ ). Consequently the total production has an average annual

Table 1. The main characteristics of soybean production

Tabela 1. Osnovna obeležja proizvodnje soje

\begin{tabular}{|c|c|c|c|c|c|c|}
\hline \multirow[t]{2}{*}{ Period } & \multirow[b]{2}{*}{$\begin{array}{l}\text { The average } \\
\text { area (ha) } \\
\text { Prosečna } \\
\text { površina }\end{array}$} & \multirow[b]{2}{*}{$\begin{array}{l}\text { Average } \\
\text { yield ( } \mathrm{t} / \mathrm{ha}) \\
\text { Prosečan } \\
\text { prinos }\end{array}$} & \multirow{2}{*}{$\begin{array}{l}\text { The average } \\
\text { production } \\
(000 \mathrm{t}) \\
\text { Prosečna } \\
\text { proizvodnja }\end{array}$} & \multicolumn{3}{|c|}{ Index $1997 / 2001=100$} \\
\hline & & & & $\begin{array}{l}\text { Area } \\
\text { Površina }\end{array}$ & $\begin{array}{l}\text { Yield } \\
\text { Prinos }\end{array}$ & $\begin{array}{l}\text { Production } \\
\text { Proizvodnja }\end{array}$ \\
\hline \multicolumn{7}{|c|}{ Republic of Serbia / Republika Srbija } \\
\hline $1997 / 2001$ & 96105 & 2.15 & 196.8 & 100 & 100 & 100 \\
\hline $2002 / 2006$ & 127267 & 2.46 & 317.2 & 132 & 115 & 161 \\
\hline $2007 / 2011$ & 154113 & 2.56 & 397.2 & 160 & 119 & 202 \\
\hline \multicolumn{7}{|c|}{ Autonomous Province of Vojvodina / AP Vojvodina } \\
\hline $1997 / 2001$ & 89296 & 2.17 & 184.5 & 100 & 100 & 100 \\
\hline $2002 / 2006$ & 119143 & 2.50 & 298.7 & 133 & 115 & 162 \\
\hline $2007 / 2011$ & 142574 & 2.58 & 370.8 & 160 & 119 & 201 \\
\hline
\end{tabular}

Source: www.stat.gov.rs and author's own calculation/ Izvor: www.stat.gov.rs i proračun autora 
Figure 1. Harvested area and average annual purchase prices of soybean (1997-2011)

Graf. 1. Kretanje požnjevenih površina i prosečnih godišnjih otkupnih cena soje (1997-2011)

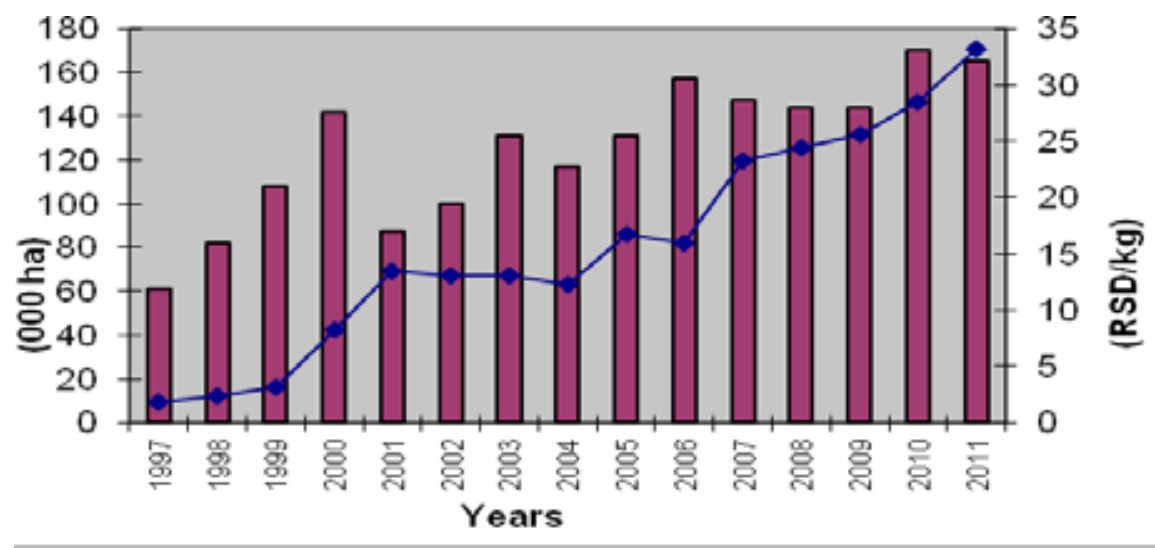

$\longrightarrow$ Average harvested area $\rightarrow$ Average annual purchase prices

Figure 2. Impact of the average annual purchase prices on the harvested area of soybean Graf. 2. Uticaj prosečnih godišnjih otkupnih cena na kretanje požnjevenih površina soje

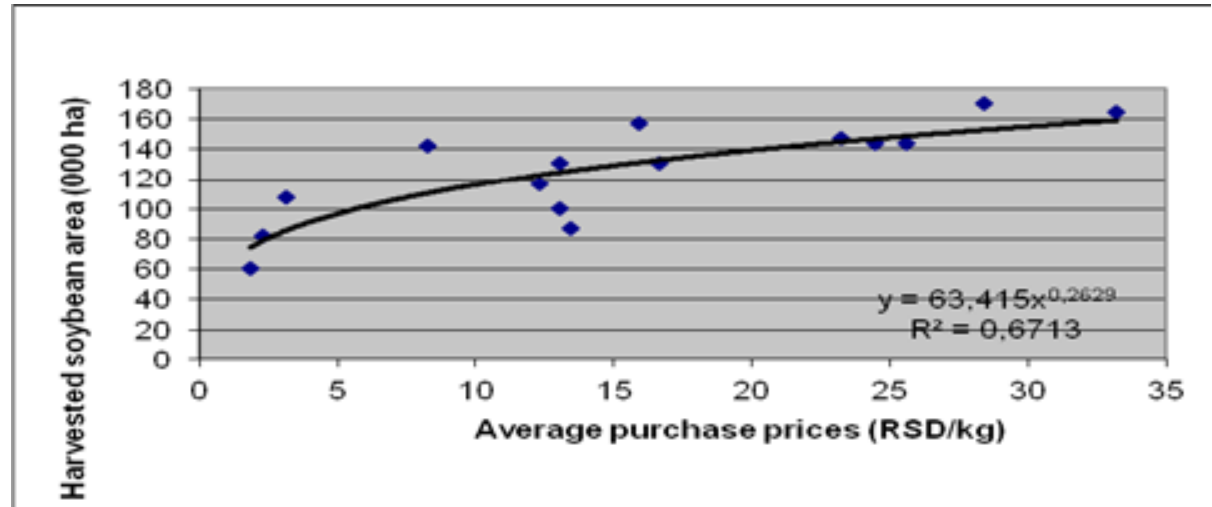

growth rate of $7.89 \%$. In the period 1997-2011 an average annual soybean production was about 304,000 tons (2.39 tons per hectare). Annual production of soybeans has been characterized by large variations both in yield $(\mathrm{CV}=20.62 \%)$ and in total production $(\mathrm{CV}$ $=37.34 \%$ ). The maximum production was registered in 2010, when it was about 541,000 tons. According to FAO data, due to this level of production Serbia became the $15^{\text {th }}$ largest soybean producer in the world.

On the one hand, positive trends registered in soybean production in Serbia are the result of the ensured sale because there are adequate processing facilities (Bašić et al. 2007), and on the other hand also of the increasing economic motivation for production of this crop due to its profitability (Bošnjak \& Rodić 2006, 2010).
The Impact of the Average Annual Purchase Prices on the Harvested Area of Soybean

Analysis of the changes of the average annual purchase prices of soybeans in the observed fifteen year period (1997-2011) indicates positive trends. The absolute values of the average annual purchase prices vary in a wide range, from $1.87 \mathrm{RSD} / \mathrm{kg}$ in 1997 to $33.17 \mathrm{RSD} / \mathrm{kg}$ in 2011 (Fig. 1).

It is evident that the pace of growth of the harvested soybean areas noted above (growth rate of $5.61 \%$ ) lags behind the increase in purchase prices of soybean (the growth rate of $20.54 \%$ ). During the fifteen-year period (1997-2011) the purchase prices of soybean demonstrate significant fluctuations. During the first fiveyear sub-period the purchase prices significantly increased (purchase price in 2001 was seven 
Table 2. The cross-correlation coefficients of the average purchase prices and the harvested area of soybean in Serbia (1997-2011)

Tabela 2. Koeficijenti kros-korelacije prosečnih otkupnih cena i požnjevenih površina soje u Srbiji (1997-2011)

\begin{tabular}{|l|l|l|}
\hline $\begin{array}{l}\text { Lag order/ } \\
\text { Red zakašnjenja }\end{array}$ & $\begin{array}{l}\text { Cross-correlation } \\
\text { Coefficients / } \\
\text { Koeficijenti } \\
\text { kros-korelacije }\end{array}$ & $\begin{array}{l}\text { The standard error / } \\
\text { Standardna greška }\end{array}$ \\
\hline-5 & 0.177778 & 0.316228 \\
\hline-4 & 0.232242 & 0.301511 \\
\hline-3 & 0.356791 & 0.288675 \\
\hline-2 & 0.547055 & 0.277350 \\
\hline-1 & $\mathbf{0 . 7 4 2 4 2 5}$ & $\mathbf{0 . 2 6 7 2 6 1}$ \\
\hline 0 & $\mathbf{0 . 7 8 9 5 0 2}$ & $\mathbf{0 . 2 5 8 1 9 9}$ \\
\hline 1 & 0.496674 & 0.267261 \\
\hline 2 & 0.335610 & 0.277350 \\
\hline 3 & 0.242802 & 0.288675 \\
\hline 4 & 0.215905 & 0.301511 \\
\hline 5 & 0.030838 & 0.316228 \\
\hline
\end{tabular}

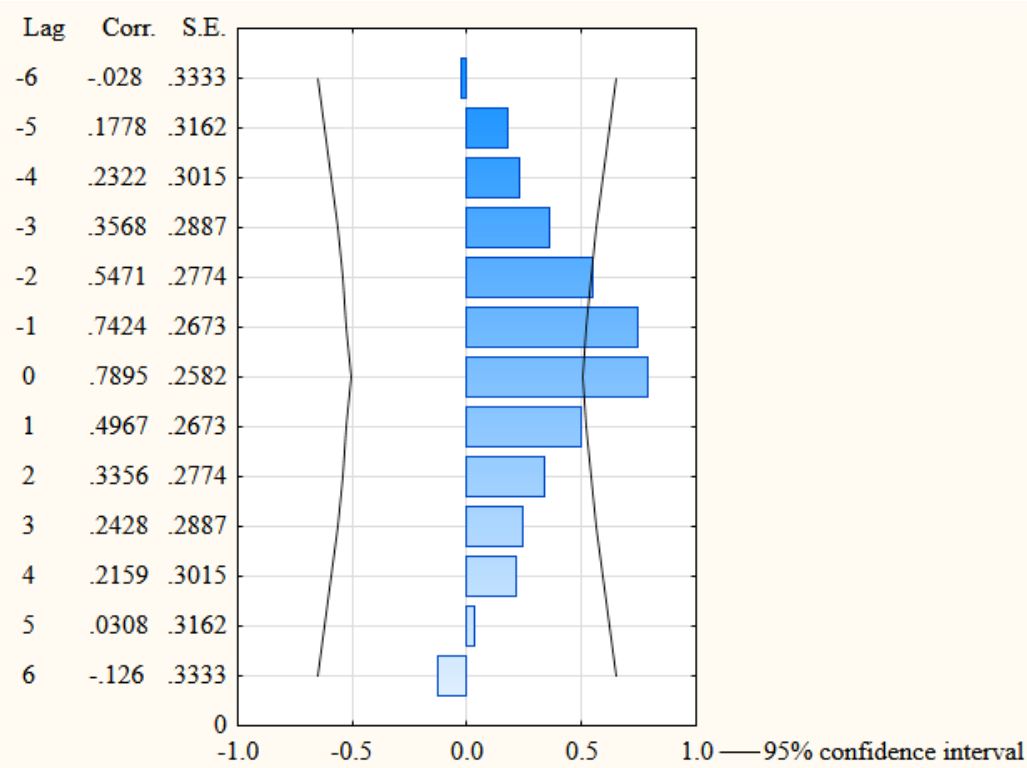

Figure 3. The values of cross-correlation coefficients and $95 \%$ confidence intervals of the average purchase prices and the harvested area of soybean in Serbia (1997-2011)

Graf. 3. Vrednosti koeficijenata kros-korelacije i 95\% intervali poverenja prosečnih otkupnih cena i požnjevenih površina soje na području Srbije (1997-2011)

times higher than in 1997). In the next five years (2002-2006) the growth was much slower and the prices were quite stable $(13.06 \mathrm{RSD} / \mathrm{kg}$ to $16.57 \mathrm{RSD} / \mathrm{kg}$ ). Then again, in the last five years of the observed period, there was somewhat more intensive growth and greater variability in purchase prices, compared to the previous fiveyear sub-period (purchase price in 2011 was 1.4 times higher than in 2007, ranging from 23.2 to $33.17 \mathrm{RSD} / \mathrm{kg}$ ), although it was much less than in the first five-year sub-period.

The established correlation between the harvested area and average annual purchase prices of soybean in the current period indicates a highly significant positive dependence of the observed variables (Fig. 2). The influence of 
the annual purchase prices $(\mathrm{x})$ on the harvested area of soybean $(Y)$ in the period 1997-2011 is modelled by means of the power regression model in the following form:

$$
\hat{Y}=63.415 \mathrm{x}^{0.2629}
$$

Based on the received power function form it could be concluded that an increase in the
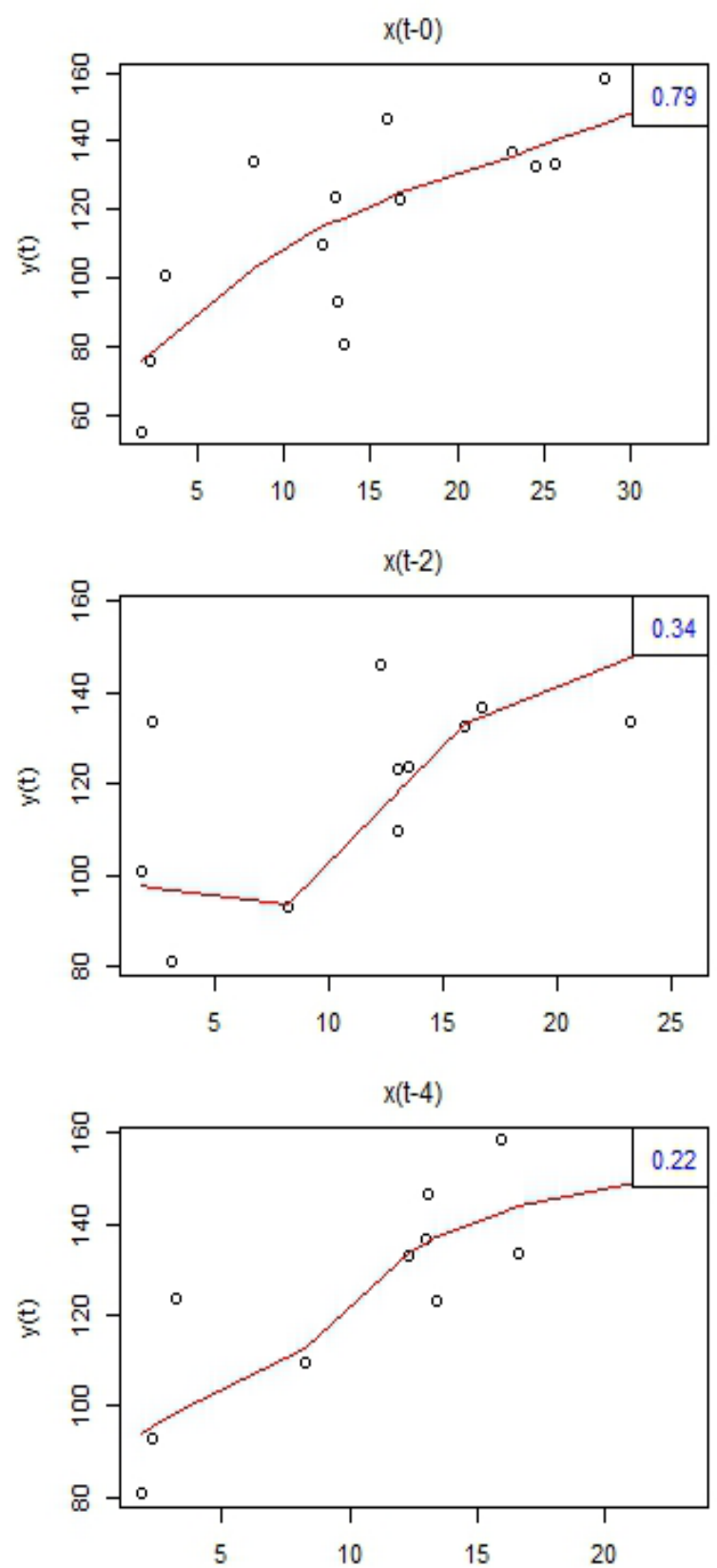

purchase price of $1 \%$ causes an increase in the soybean area by $0.26 \%$. The obtained value of the coefficient of determination $\left(\mathrm{R}^{2}=0.67\right)$ indicates that $67 \%$ of the change in the harvested area could be explained by variations of the current purchase prices.

Cross-correlation function was used to investigate the lag effect of the average annual purchase prices of soybean on the harvested

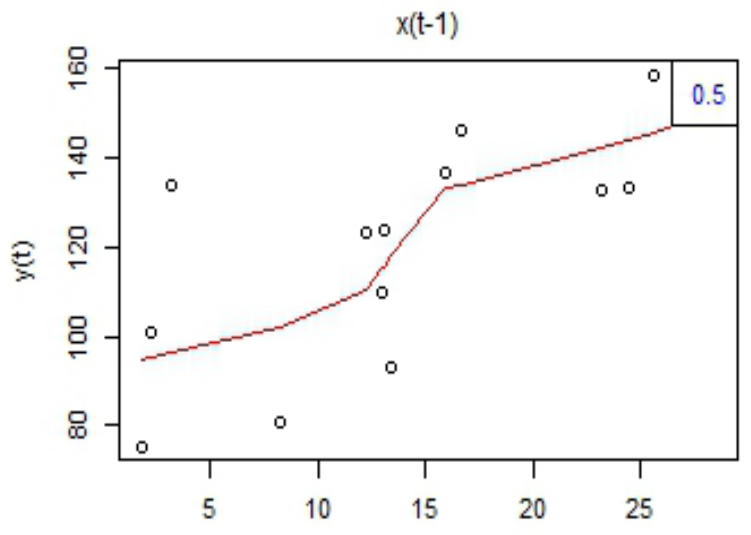

$x(t-3)$
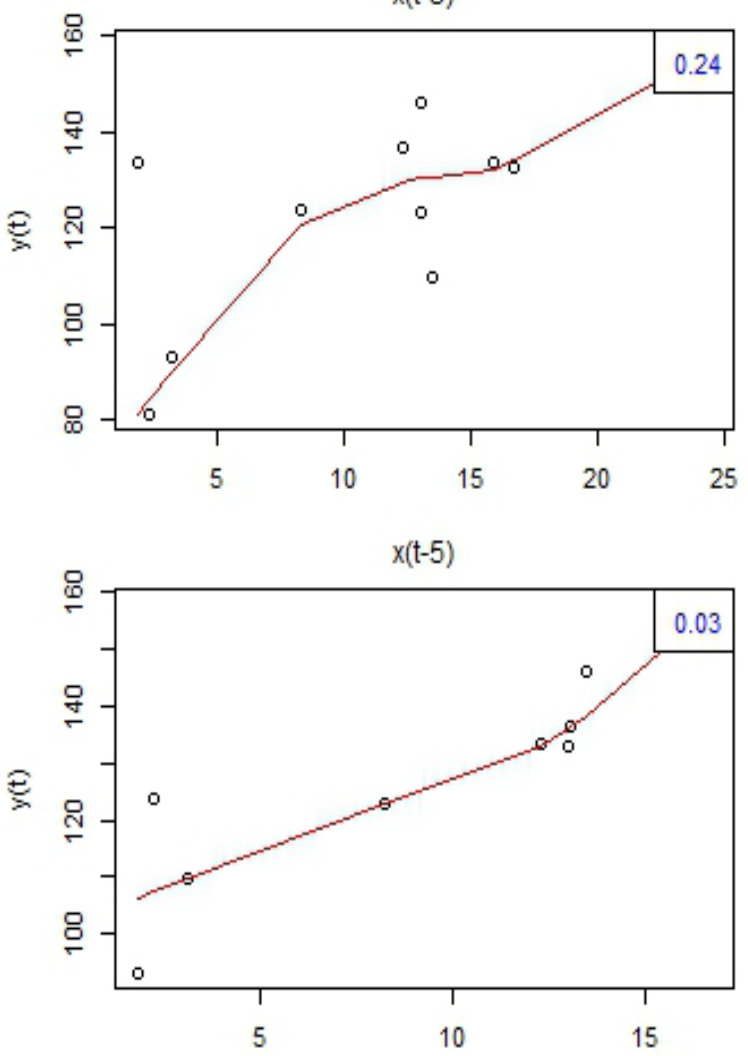

Figure 4. Correlation of the harvested areas and lagged values of the average purchase price of soybean $(1997-2011)$

Graf. 4. Korelacija požnjevenih površina i zakasnelih vrednosti prosečnih cena soje (1997-2011) 
area of soybean. Calculated values of crosscorrelation coefficients are shown in Table 2.

From the obtained cross-correlation coefficients, based on the lag effects of the purchase prices of soybean on the harvested area of this crop, one can conclude that there is no statistically significant correlation between the harvested area in the current year and the average purchase prices of soybean from

$y(t-0)$

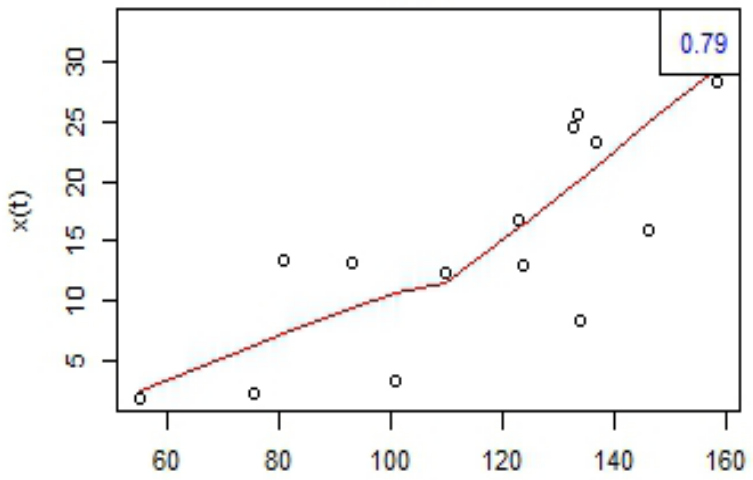

$y(t-2)$

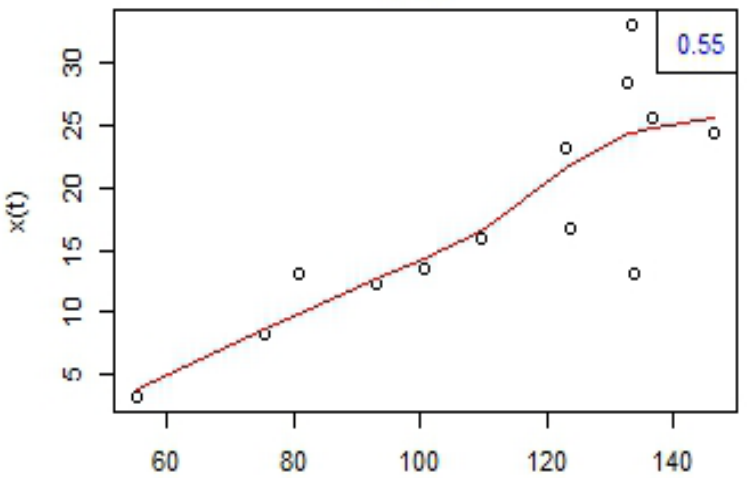

$y(t-4)$

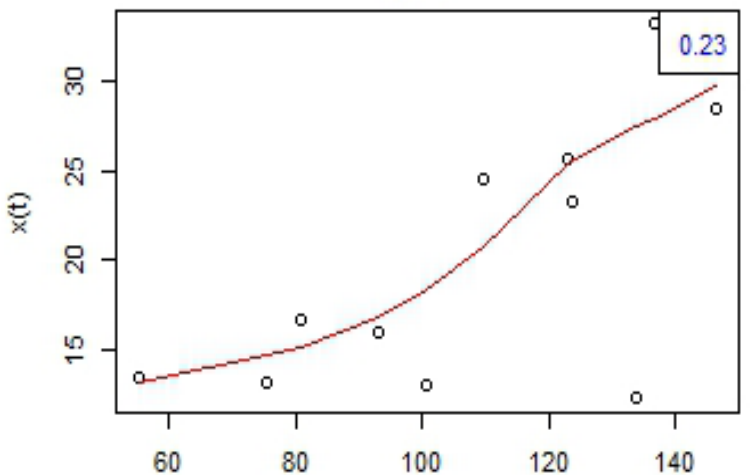

the previous years. The lack of statistically significant correlation has clearly been shown in Figure 3.

The intensity of correlation between the harvested areas and the purchase prices of soybean in the previous period, with the 0-5 lags, is shown in Figure 4. The established values of correlation coefficients, which are relatively low and decrease as the degree of delay increases $(0.5$;

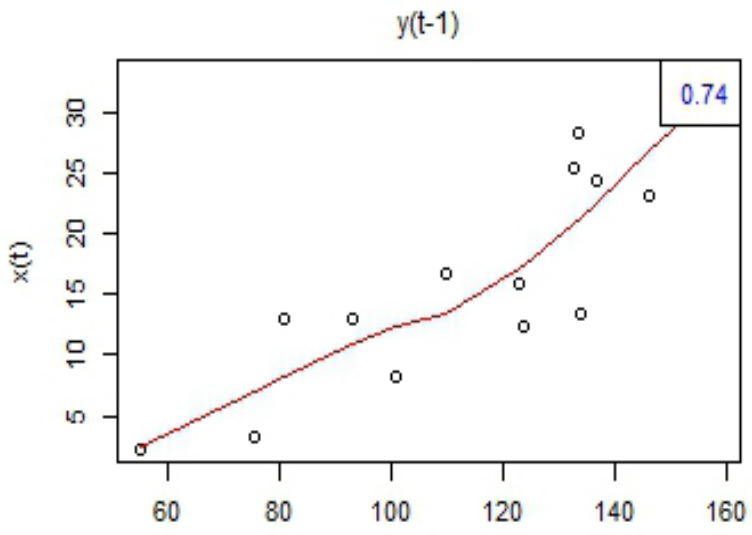

$y(t-3)$

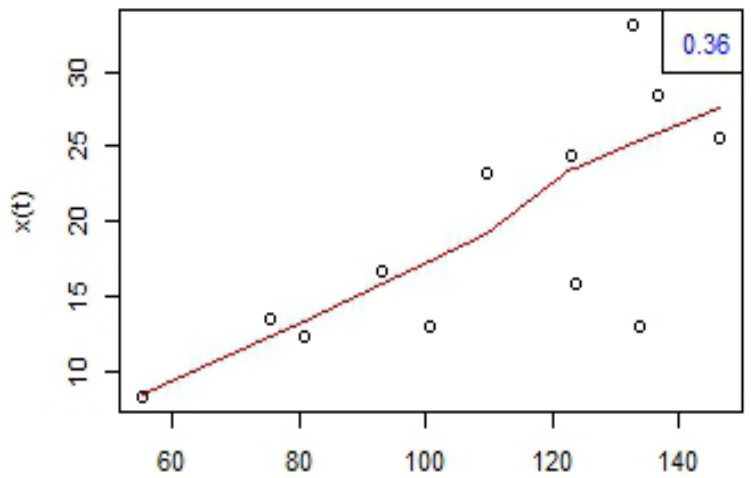

$y(t-5)$

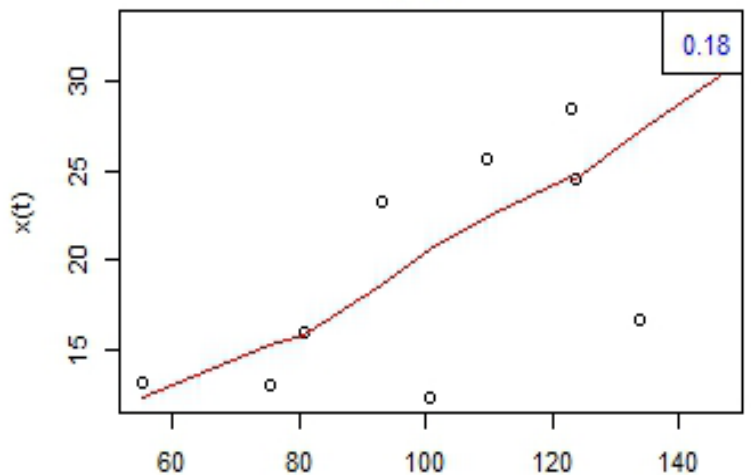

Figure 5. Correlation between the purchase prices and the harvested soybean areas in the previous period (19972011)

Graf. 5. Korelacija otkupnih cena i požnjevenih površina soje iz prethodnih perioda (1997-2011) 
$0.34 ; 0.24 ; 0.22$ and 0.03 ), lead to the conclusion drawn above, that there is no statistically significant correlation between the harvested areas and lagged values of the average purchase prices of soybean.

Given the previously established positive highly significant dependence of the average purchase price and the annual harvested area of soybeans in the current period, the lag effects in the opposite direction, i.e. the impact of the harvested areas from the previous period on the average annual purchase prices of soybean in the current year was examined, using the crosscorrelation function.

In contrast to the previously established correlations, it could be concluded that the harvested areas from the previous year are in statistically significant correlation with the purchase prices in the current year. This is evidenced by the determined values of correlation coefficients (Figure 5), since the highest value of the coefficient (0.74) was found for one year delay.

The established dependence is a consequence of the influence of the harvested areas on the total volume of production, which further influences the purchase prices of soybean through the supply/demand mechanism on the market. This confirms the earlier research of Mutavdžić et al. (2006), which was based on a longer time series and which indicates particularly high influence of the achieved total volume of production in the current year on soybean sowing areas in the following year.

The obtained results indicate that for the observed period (1997-2011) the starting hypothesis should be rejected. The reason for this could be partly found in the length of the analysed period, since it is known that the use of cross-correlation gives more reliable results when longer time series are analysed. However, this kind of late dependence cannot be completely ruled out given that Milanović \& Stevanović (2012) did find a highly significant correlation between the current purchase prices of soybean and the sowing areas of this crop in the following year (they observed the period 2001-2010, which is even shorter than the period observed in this paper).

Soybean is increasingly becoming a commodity whose producers act according to market conditions (Galetin 2011). The fact is, also, that the purchase prices are a significant factor of the effectiveness of each crop, including soybean. If we bear in mind the above mentioned, it could be expected that the stabilization of the supply and demand will exert stabilization of the average annual purchase prices of soybean on the one hand, and a stronger effect of the purchase price on the producers' decision about the growing areas for soybean on the other hand. This imposes the need for further monitoring of the observed characteristics of soybeans in order to obtain more reliable results in a repeated study in the future, on the basis of which one could make a valid management decision.

\section{Conclusion}

During the observed period of fifteen years (1997-2011), the pace of growth of the harvested soybean areas (growth rate of 5.61\%) lags behind the increase in the purchase prices of soybean (the growth rate of $20.54 \%$ ).

A highly significant $\left(\mathrm{R}^{2}=0.67\right)$ positive dependence was found between soybean harvested areas and the average current purchase prices. Based on the received power function form, it could be concluded that an increase in the purchase price of $1 \%$ causes an increase of $0.26 \%$ in the soybean area.

From theobtainedcross-correlationcoefficients, based on the lag effects of the purchase prices of soybean on the harvested area, one can conclude that there is no statistically significant correlation between the harvested area in the current year and the average purchase prices of soybean from the previous years. However, there is a statistically significant correlation between the harvested areas from the previous year and the purchase prices in the current year. Thus, based on the analysis given in this paper one could expect further growth of the average purchase prices of soybean in Serbia, given the expressed tendencies of growth of the harvested soybean areas on the one hand, and the established correlation between the harvested areas and the purchase prices on the other hand. Of course, soybean prices are and will be influenced by many other factors, including trends in regional and world market prices. It could be expected that with stabilization of the supply and demand in the future, the impact of purchase prices on producers' decision about soybean growing areas will increase in the coming years. 


\section{References}

Bašić, Đ., Tešić, M., Kiš, F., Janković, V., Furman, T., Marinković, R., ... Mulić, R. (2007). Moguínost proizvodnje i korišćenja biodizela u AP Vojvodini - studija. (p. 184) Novi Sad: Fakultet tehničkih nauka.

Birovljev, J. (2001). Agrarna politika - cena kao bitan faktor poslovanja preduzeća agrobiznis. Anali ekonomskog fakulteta $u$ Subotici, 6, 237-246.

Birovljev, J., \& Tomić, R. (2009). Menadžment u agrobiznisu. Subotica: Ekonomski fakultet.

Bošnjak, D. (2012). Regionalni razmestaj proizvodnje soje u Vojvodini. Ratar. Povrt., 49(2), 214-219.

Bošnjak, D., \& Rodić, V. (1999). Obeležja ratarske proizvodnje u Vojvodini i mogućnosti njenog prestruktuiranja.Agroekonomika, 28, 93-105.

Bošnjak, D., \& Rodić, V. (2006). Ekonomska obeležja proizvodnje soje. Zbornik radova Instituta za ratarstvo i povrtarstvo, 42(2), 117-128.

Bošnjak, D., \& Rodić, V. (2010). Kokurentnost osnovnih ratarskih useva u Vojvodini. Ratar. Povrt., 47(2), 607-612.

Bošnjak, D., \& Rodić, V. (2011). The place of soybean in the crop planting structure in Vojvodina. U: Proc. of the 22nd International Simposium Food safety production (XXII), Trebinje, Bosnia and Herzegovina, Proceedings. 149-152.

Box, G.E.P., Jenkins, G.M., \& Reinsel, G.C. (2008). Time Series Analysis, Forecasting and Contro, 4thed. Hoboken, New Jersey: John Wiley \& Sons, Inc..

Brodt, S., Klonsky, K., \& Tourte, L. (2006). Farmer goals and management styles: Implications for advancing biologically based agriculture. Agricultural Systems, 89(1), 90-105. doi:10.1016/j. agsy.2005.08.005

Burton, J.W., \& Miranda, L. (2013). Soybean Improvement: Achievements and Challenges, Ratar. Povrt. 50 (2), 44-51, doi: $10.5937 /$ ratpov50-4158

Galetin, Ž. (2011). Sigurne informacije i dobre procene. Accessed from www.proberza.co.rs/sigurne-informacije-i-dobre-procene on 2013 Aug 21.

Republički zavod za statistiku. (2013). Diseminaciona baza podataka. Retrieved from http://webrzs.stat.gov.rs/WebSite/ public/ReportView.aspx on $2013 \mathrm{Feb} 12$.

Milanović, M. (1996). Politika cena poljoprivrednih proizvoda. Beograd: Društvo agrarnih ekonomista Jugoslavije.

Milanović, M.R. (2011). Ekonomske promene na reprodukcionoj vertikali industrije ulja u Srbiji - dugoročni trendovi. Industrija, 39(4), 107-126.

Milanović, M., \& Stevanović, S. (2012). Models of regression of the scope of sown areas and purchase prices of oil crops in Serbia. Economic Research, 25(4), 1017-1032.

Müller, S.L., \& Abisya, S.T. (2001). Culture and entrepreneurial potential: A nine-country study of locus of control and innovativeness. Journal of Business Venturing, 16(1), 51-75.

Mutavdžić, B., Novković, N., Nikolić-Djorić, E., \& Radojević, V. (2006). Uticaj ukupne proizvodnje na setvenu strukturu značajnih ratarskih useva. Ekonomika poljoprivrede, 2, 389-401.

Reljin, S., Jovanović, M., \& Tica, N. (1997). Soja - ekonomika proizvodnje. Bečej: Sojaprotein.

Starčević, L., Latković, D., \& Crnobarac, J. (2003). Stanje i mogući pravci razvoja ratarske proizvodnje u Vojvodini.Zbornik radova Instituta za ratarstvo i povrtarstvo, 38, 5-19.

Vlahović, B. (2003). Tržište poljoprivredno prehrambenih proizvoda, Opšti deo- knjiga 1. Novi Sad: Poljoprivredni fakultet.

\title{
Međusobna uslovljenost požetih površina i otkupnih cena soje
}

\author{
Danica Bošnjak • Emilija Nikolić Đorić • Vesna Rodić
}

Sažetak: Dominantno i stalno aktuelno pitanje pri donošenju poslovnih odluka na poljoprivrednim gazdinstvima jeste šta proizvoditi, odnosno za kakvu strukturu setve se opredeliti. Ekonomski faktori i principi imaju značajnu ulogu u opredeljenju poljoprivrednih proizvođača koji usev će sejati i na kojoj površini. Otkupna cena svakog useva, pa samim tim i soje, jeste bitan, ali ne i jedini faktor konkurentnosti. Autori u ovom radu polaze od pretpostavke da nivo i kretanje otkupnih cena soje, između ostalog, utiču na odluku proizvođača o tome na kojoj će površini gajiti ovaj usev. Stoga je učinjen pokušaj da se primenom odgovarajućih regresionih modela ispita i oceni međusobna uslovljenost prosečnih otkupnih cena i požnjevenih površina soje u Srbiji, kako bi polazne pretpostavke bile i naučno potvrđene.

Ključne reči: kros-korelaciona funkcija, požete površine, prosečne otkupne cene, soja, stepena regresija, zakasnela korelacija 